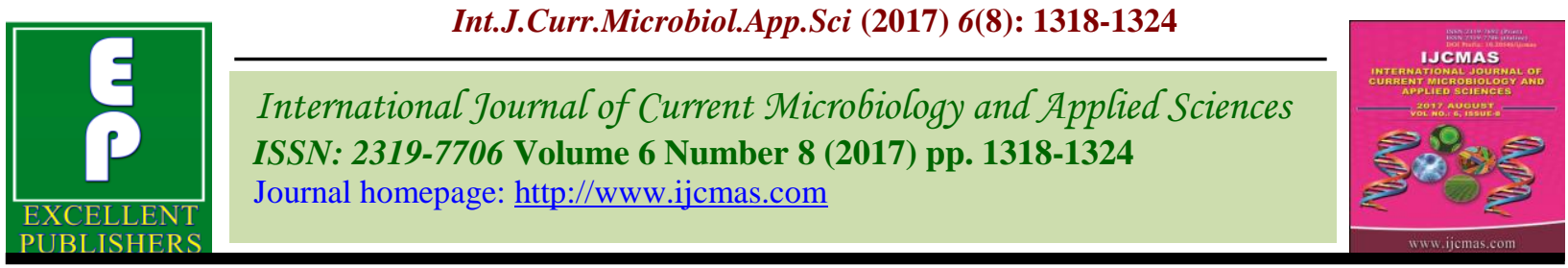

Original Research Article

https://doi.org/10.20546/ijcmas.2017.608.160

\title{
Screening of Castor Genotypes for Ricinoleic Acid Content
}

\author{
S.K. Shah*, A.V. Joshi, A.M. Patel and D.K. Patel \\ ${ }^{1}$ Castor and Mustard Research Station, S.D. Agricultural University, Sardarkrushinagar \\ (Gujarat) 385 506, India \\ *Corresponding author
}

\section{A B S T R A C T}

\section{Keywords}

Castor, Ricinoleic

acid, Fatty acid,

Oil stability

index.

\section{Article Info}

Accepted:

17 June 2017

Available Online:

10 August 2017
Fourteen castor genotypes including two checks GC 3 and GCH 7 were grown in irrigated condition with recommended agronomic practices. The seeds were harvested at stage of their physiological maturity. The soil properties, seed quality parameters, fatty acid profile, ricinoleic acid were analysed as per standard methods. The highest value of 100 seed wt $39.0 \mathrm{~g}$ was determined in genotype RG 380 and the highest seed yield was found in RG 63 (4987 kg/ha). The highest seed oil content was determined in RG 311, RG 330 genotypes which was $50.7 \%$ and $50.6 \%$, respectively. Ricinoleic acid, the predominant monounsaturated fatty acid varied among castor genotypes from 85.10 (RG 311) to 89.83 (RG 357). In the present study, the ricinoleic acid content was significantly negatively correlated with palmitic acid $\left(\mathrm{r}=-0.869^{* *}\right)$; stearic acid $\left(\mathrm{r}=-0.877^{* *}\right)$; oleic acid $(\mathrm{r}=-$ $\left.0.967^{* *}\right)$; linoleic acid $\left(\mathrm{r}=-0.978^{* *}\right)$ and with linolenic acid $\left(\mathrm{r}=-0.676^{* *}\right)$. The Oleic (MUFA) / Ricinoleic acid ratio among the all 14 genotypes varied from 0.037 (RG 357) to 0.057 (RG 311). The present study is vital for selecting male parent for developing castor hybrids for high ricinoleic acid.

\section{Introduction}

Castor (Ricinus communis L.) is an important non-edible oilseed crop of Euphorbiaceae family. Castor has enormous significance in the country as it plays an important role in the agricultural economies because it enables them to earn substantial foreign exchange through export of castor beans and oils. It is believed that castor is indigenous to the southeastern Mediterranean Basin, Eastern Africa and India. Castor is grown throughout the tropical, warm temperate and subtropical regions between latitudes $40^{\circ}$ South and $52^{\circ}$ North in the world, but the commercial cultivation of castor is carried out in about 30 countries especially in arid and semi-arid region. About 90 per cent of the world's total castor is grown in India, China and Brazil. India with almost 65 per cent share in castor and its derivatives production enjoys an almost monopolistic situation in world. Gujarat, Rajasthan and Andhra Pradesh are the major castor growing states in India.

Castor seed is the source of castor oil which varies from $45 \%$ to $51 \%$. Apart from castor oil the de-oiled cake (DOC)/meal serves primarily as an organic fertilizer. The presence of a unique fatty acid i.e. ricinoleic acid (12-hydroxy, 9-octadecenoic acid) makes castor oil suitable for many industrial usages. Ricinoleic acid has three functional groupshydroxyl, carboxylate and carbon-carbon 
double bond (alkene) (Mutlu et al., 2010). It is the only source of an 18-carbon hydroxylated fatty acid with one double bond in each of the fatty acid chain and ricinoleic acid make up about $89 \%$ of the fatty acid composition. The other fatty acids found in the castor oil are oleic, stearic, palmitic, linoleic, dihydroxystearic acid, linolenic acid and eicosanoic acid. Castor oil is used to make soap, detergent and other forms of the oil are important for the treatment of leather, industrial lubricants, and other industrial uses (Isah et al., 2006). The dehydrated oil is an excellent drying agent which compares favourably with tung oil and is used in paints and varnishes and hydrogenated oil is used in the manufacture of waxes, plastics, carbon paper, candles and crayons. In food processing industry it is used as an additive for flavouring and also as a mould inhibitor. Castor is used even in anti-cancer therapy and in the treatment of skin ulcers. Castor oil is also regarded as one of the most valuable laxatives in medicine. In modern-day medicine, castor oil is also used as a drug delivery vehicle. An example is Cremophor EL. It is also often used as a drug delivery vehicle for very non-polar drugs such as the anticancer drugs paclitaxel and docetaxel. Other novel uses of castor oil and its derivatives include nylon-6, 10 from sebacic acid, nylon-11 from 11-aminoundecanoic acid. Castor oil is neither becomes stiff with cold nor thin with heat therefore is used for lubricant in jet and racing cars engines. Castor oil properties indicate a very low pour and cloud points which make suitable as bio fuel (Shah et. al., 2014).

\section{Materials and Methods}

Fourteen castor genotypes including two checks GC 3 and $\mathrm{GCH} 7$ were grown in irrigated condition at Castor-Mustard Research station, S.D.A.U., Sardarkrushinagar, Gujarat (India). Standard agronomic practices were practiced for the crop production. The seeds were harvested at stage of their physiological maturity. The soil samples were collected from $0-15 \mathrm{~cm}$ depth before sowing of the crop and after the harvesting of crop. In the present study the soil profile parameters like $\mathrm{pH}, \mathrm{EC}, \mathrm{O} . \mathrm{C}(\%)$, Avail. N (Kg/ha), Avail. $\mathrm{P}_{2} \mathrm{O}_{5}(\mathrm{Kg} / \mathrm{ha})$, Avail. $\mathrm{K}_{2} \mathrm{O}$ (Kg/ha), Avail. S (ppm) was determined (Table 1).

\section{Quality parameters of seed}

100 seed weight $(\mathrm{g})$, seed oil content $(\%)$, seed yield ( $\mathrm{kg} / \mathrm{ha}$ ), fatty acids (Palmitic, Stearic, Oleic, Linoleic, Linolenic and Ricinoleic acid) composition (\%) were determined as per standard methods.

\section{Seed oil content $(\%)$}

The Seed oil content of castor seeds were calculated on Nuclear Magnetic Resonance Spectroscopy ( NMR) instrument (MQC model, Oxford instruments) as per method described by Yadav and Murthy (2016).

\section{Seed yield (kg/ha)}

The seeds were harvested manually in each experimental plot at maturity and weighed in $\mathrm{g} /$ plot with the help of a weighing balance and then convert into $\mathrm{kg} / \mathrm{ha}$.

\section{Fatty acid composition}

Fatty acid profile of oil of different genotypes of castor performed on Thermo Gas chromatography (GC-FID, Trace GC Ultra) using Fatty Acid Methyl Esters (FAMEs) of castor oil as described by FSSAI, 2015.

\section{Oil stability index}

Oleic and Linoleic acid (O/L) ratio were computed, as oil stability index. 


\section{Results and Discussion}

\section{Soil quality parameter}

The soils of experimental site were neutral in soil reaction, low in electrical conductance. Nutrient content of experimental site was as follows: Available $\mathrm{N}$ was low; Available $\mathrm{P}_{2} \mathrm{O}_{5}$ was medium; Available $\mathrm{K}_{2} \mathrm{O}$ was low and Available $\mathrm{S}$ was medium (Table 2).

\section{Seed quality parameters}

The seed quality parameters are the most important quality parameter which determines the price of seeds at the time of sale. In the present study among the all genotypes analysed, the highest value of 100 seed wt $39.0 \mathrm{~g}$ was determined in genotype RG 380 and lowest value of $17.0 \mathrm{~g}$ was determined in genotype RG 2451 (Table 3). Seed weight is an important characteristic for milling. The highest seed yield was found in RG 63 (4987 $\mathrm{kg} / \mathrm{ha}$ ), RG 311 (4408 kg/ha) and RG 358 (4373 kg/ha) genotypes with compared to that of the hybrid varieties GCH 7 (4275 kg/ha) and GC 3 (2205 g/net plot) which was kept as control. The highest value of seed oil content was determined in $\mathrm{RG} 311, \mathrm{RG} 330$ genotypes which was $50.7 \%$ and $50.6 \%$ respectively and lowest value $47.8 \%$ of seed oil content was determined in RG 2685 genotype with compared to that of checks. The better oil yield makes industrial practice of oil recovery a profitable venture (Abitogun et al., 2009).

\section{Fatty acid profile}

Saturated fatty acid, palmitic and stearic acids were in the range of $1.02-1.64 \%$ and 1.18$1.93 \%$, respectively (Table 4). Significant positive correlation was observed between palmitic cid and stearic acid $\left(\mathrm{r}=0.702^{* *}\right)$. Mono unsaturated fatty acid (MUFA) - oleic acid varied from $3.28 \%$ ( $\mathrm{RG} 357$ ) to $4.88 \%$
(RG 311). Higher value of oleic acid is a desirable trait for high oxidative stability, hence suitability of castor oil for industrial usage (Rojas et al., 2004). The oleic acid showed significantly positive correlation with palmitic acid ( $\left.\mathrm{r}=0.786^{* *}\right)$ and stearic acid ( $\mathrm{r}$ $=0.832 * *)$. These results were resembled with the findings of Shah et al., (2014).

The Poly unsaturated fatty acid (PUFA) linoleic and linolenic fatty acid were in range of $4.17 \%$ to $5.96 \%$ and $0.45 \%$ to $0.73 \%$, respectively. The linoleic acid has significantly positive correlation with palmitic acid $\left(\mathrm{r}=0.865^{* *}\right)$, stearic acid $\left(\mathrm{r}=0.793^{*}\right)$ and oleic acid $\left(\mathrm{r}=0.918^{* *}\right)$. However, the linolenic acid has positive correlation with stearic acid $\left(\mathrm{r}=0.570^{*}\right)$, oleic acid $(\mathrm{r}=$ $0.647 * *)$ and linoleic acid $(\mathrm{r}=0.664 * *)$ (Table 7). Ricinoleic acid, the predominant monounsaturated fatty acid varied among castor genotypes from 85.10 (RG 311) to 89.83 (RG 357). Ricinoleic acid was higher $(85.1 \%-89.8 \%)$ than other fatty acids in the castor oil and compares well with literature. In the present study, the ricinoleic acid content was significantly negatively correlated with palmitic acid $\left(\mathrm{r}=-0.869^{* *}\right)$; stearic acid $\left(\mathrm{r}=-0.877^{* *}\right)$; oleic acid $(\mathrm{r}=-$ $\left.0.967^{* *}\right)$; linoleic acid $\left(\mathrm{r}=-0.978^{* *}\right)$ and with linolenic acid $\left(r=-0.676^{* *}\right)$. The hydroxyl functionality of ricinoleic acid (RA) makes the castor oil a natural polyol providing oxidative stability to the oil, and a relatively high shelf life compared to other oils by preventing peroxide formation. Castor oil can be stored for long periods without appreciable deterioration for periods up to two years. The functional group causes ricinoleic acid to be usually polar and also allows chemical derivatization that is not practically possible with most other vegetable oils. Results of present study of fatty acid profile resembled with the findings of Lakshminarayana et al., (1984). 
Table.1 Methods used for determination of soil properties

\begin{tabular}{|l|l|}
\hline \multicolumn{1}{|c|}{ Parameter } & \multicolumn{1}{c|}{ Method } \\
\hline $\mathrm{pH}(1: 2.5)$ & $1: 2.5$ soil water suspension- (Jackson, 1967) \\
\hline $\mathrm{EC}(1: 2.5)$ & $1: 2.5$ soil water suspension- (Piper,1950) \\
\hline O.C $(\%)$ & Walkley and Black (1947) \\
\hline Avail. $\mathrm{N}(\mathrm{Kg} / \mathrm{ha})$ & Subbiah and Asija (1956) \\
\hline Avail. $\mathrm{P}_{2} \mathrm{O}_{5}(\mathrm{Kg} / \mathrm{ha})$ & Olsen's method (Jackson, 1967) \\
\hline Avail. $\mathrm{K}_{2} \mathrm{O}(\mathrm{Kg} / \mathrm{ha})$ & $\begin{array}{l}\text { Ammonium acetate method using flame photometer } \\
\text { (Chapman and Pratt, 1961) }\end{array}$ \\
\hline Avail. $\mathrm{S}(\mathrm{ppm})$ & Turbidimetric method (Chesnin and Yien, 1950) \\
\hline
\end{tabular}

Table.2 Soil properties of experimental site

\begin{tabular}{|l|c|}
\hline Parameter & Value \\
\hline $\mathrm{pH}(1: 2.5)$ & 7.4 \\
\hline $\mathrm{EC}(1: 2.5)$ & 0.03 \\
\hline O.C. $\%$ & 0.25 \\
\hline Avail. $\mathrm{N}(\mathrm{kg} / \mathrm{ha})$ & 104 \\
\hline Avail $\mathrm{P}_{2} \mathrm{O}_{5}(\mathrm{~kg} / \mathrm{ha})$ & 52 \\
\hline Avail $\mathrm{K}_{2} \mathrm{O}(\mathrm{kg} / \mathrm{ha})$ & 169 \\
\hline Avail $\mathrm{S}(\mathrm{ppm})$ & 11.2 \\
\hline
\end{tabular}

Table.3 Determination of seed quality characteristics of castor genotypes

\begin{tabular}{|l|c|c|c|}
\hline Genotype & Oil content (\%) & 100 Seed weight (g) & Seed yield (kg/ha) \\
\hline RG 2685 & 47.8 & 38 & 3270 \\
\hline RG 226 & 49.0 & 34 & 4043 \\
\hline RG 2451 & 47.9 & 17 & 1608 \\
\hline RG 311 & 50.7 & 34 & 4408 \\
\hline RG 329 & 50.0 & 34 & 2962 \\
\hline RG 330 & 50.6 & 38 & 3370 \\
\hline RG 3445 & 48.8 & 35 & 1044 \\
\hline RG 3451 & 49.2 & 32 & 1434 \\
\hline RG 3467 & 49.7 & 34 & 3694 \\
\hline RG 357 & 49.1 & 35 & 3685 \\
\hline RG 358 & 49.3 & 31 & 4373 \\
\hline RG 370 & 49.6 & 25 & 3036 \\
\hline RG 380 & 48.7 & 39 & 2865 \\
\hline RG 63 & 49.3 & 33 & 4987 \\
\hline GC 3 (C) & 50.2 & 32 & 3351 \\
\hline GCH 7 (C) & 49.7 & 33 & 4275 \\
\hline
\end{tabular}


Int.J.Curr.Microbiol.App.Sci (2017) 6(8): 1318-1324

Table.4 Fatty acid composition of castor genotypes

\begin{tabular}{|c|c|c|c|c|c|c|}
\hline \multirow[t]{3}{*}{ Genotype } & \multicolumn{2}{|c|}{ SFA } & \multirow{2}{*}{$\begin{array}{c}\text { MUFA } \\
\text { Oleic }\end{array}$} & \multicolumn{2}{|c|}{ PUFA } & \multirow{2}{*}{$\begin{array}{c}\text { RA } \\
\text { Ricinoleic }\end{array}$} \\
\hline & Palmitic & Stearic & & Linoleic & Linolenic & \\
\hline & $16: 0$ & $18: 0$ & $18: 1$ & $18: 2$ & $18: 3$ & 18:1 (OH) \\
\hline RG 2685 & 1.25 & 1.56 & 4.10 & 5.05 & 0.65 & 87.39 \\
\hline RG 226 & 1.31 & 1.76 & 4.78 & 5.34 & 0.73 & 86.08 \\
\hline RG 2451 & 1.21 & 1.84 & 4.04 & 4.66 & 0.57 & 87.68 \\
\hline RG 311 & 1.56 & 1.93 & 4.88 & 5.96 & 0.57 & 85.10 \\
\hline RG 329 & 1.57 & 1.89 & 4.78 & 5.90 & 0.71 & 85.15 \\
\hline RG 330 & 1.64 & 1.78 & 4.64 & 5.60 & 0.63 & 85.71 \\
\hline RG 3445 & 1.36 & 1.46 & 4.30 & 5.50 & 0.66 & 86.72 \\
\hline RG 3451 & 1.17 & 1.51 & 4.44 & 5.18 & 0.68 & 87.02 \\
\hline RG 3467 & 1.10 & 1.24 & 3.89 & 4.29 & 0.52 & 88.96 \\
\hline RG 357 & 1.05 & 1.18 & 3.28 & 4.17 & 0.49 & 89.83 \\
\hline RG 358 & 1.02 & 1.33 & 3.57 & 4.42 & 0.53 & 89.13 \\
\hline RG 370 & 1.46 & 1.34 & 4.03 & 4.91 & 0.51 & 87.75 \\
\hline RG 380 & 1.10 & 1.38 & 3.97 & 4.67 & 0.54 & 88.34 \\
\hline RG 63 & 1.35 & 1.64 & 4.37 & 5.11 & 0.59 & 86.94 \\
\hline GC $3(\mathrm{C})$ & 1.32 & 1.67 & 4.44 & 5.17 & 0.55 & 86.85 \\
\hline $\mathrm{GCH} 7(\mathrm{C})$ & 1.27 & 1.43 & 4.18 & 4.78 & 0.45 & 87.89 \\
\hline
\end{tabular}

Table.5 Comparison of Saturated Fatty Acid (SFA) and Unsaturated Fatty Acid (UFA) in different castor genotypes

\begin{tabular}{|c|c|c|c|c|c|}
\hline Genotype & SFA & MUFA & PUFA & RA & UFA \\
\hline RG 2685 & 2.80 & 4.10 & 5.70 & 87.40 & 97.20 \\
\hline RG 226 & 3.07 & 4.78 & 6.07 & 86.08 & 96.93 \\
\hline RG 2451 & 3.05 & 4.04 & 5.23 & 87.68 & 96.95 \\
\hline RG 311 & 3.49 & 4.88 & 6.53 & 85.10 & 96.51 \\
\hline RG 329 & 3.46 & 4.78 & 6.61 & 85.15 & 96.54 \\
\hline RG 330 & 3.40 & 4.64 & 6.27 & 85.71 & 96.60 \\
\hline RG 3445 & 2.82 & 4.30 & 6.16 & 86.72 & 97.18 \\
\hline RG 3451 & 2.67 & 4.44 & 5.85 & 87.04 & 97.33 \\
\hline RG 3467 & 2.34 & 3.89 & 4.80 & 88.96 & 97.66 \\
\hline RG 357 & 2.23 & 3.28 & 4.66 & 89.83 & 97.77 \\
\hline RG 358 & 2.35 & 3.57 & 4.95 & 89.13 & 97.65 \\
\hline RG 370 & 2.79 & 4.03 & 5.42 & 87.76 & 97.21 \\
\hline RG 380 & 2.48 & 3.97 & 5.20 & 88.35 & 97.52 \\
\hline RG 63 & 2.99 & 4.37 & 5.70 & 86.94 & 97.01 \\
\hline GC 3 (C) & 2.99 & 4.44 & 5.72 & 86.85 & 97.01 \\
\hline GCH 7 (C) & 2.70 & 4.18 & 5.23 & 87.89 & 97.30 \\
\hline
\end{tabular}


Table.6 Computation of different ratios among fatty acids of castor genotypes

\begin{tabular}{|c|c|c|}
\hline Oleic/Linoleic (O/L) & MUFA/PUFA & MUFA/RA \\
\hline 0.81 & 0.72 & 0.047 \\
\hline 0.89 & 0.79 & 0.055 \\
\hline 0.87 & 0.77 & 0.046 \\
\hline 0.82 & 0.75 & 0.057 \\
\hline 0.81 & 0.72 & 0.056 \\
\hline 0.82 & 0.74 & 0.054 \\
\hline 0.78 & 0.70 & 0.050 \\
\hline 0.86 & 0.76 & 0.051 \\
\hline 0.91 & 0.81 & 0.044 \\
\hline 0.79 & 0.70 & 0.037 \\
\hline 0.81 & 0.72 & 0.040 \\
\hline 0.82 & 0.74 & 0.046 \\
\hline 0.85 & 0.76 & 0.045 \\
\hline 0.85 & 0.77 & 0.050 \\
\hline 0.86 & 0.78 & 0.051 \\
\hline 0.87 & 0.80 & 0.048 \\
\hline & &
\end{tabular}

Table.7 Correlation coefficient among different fatty acids

\begin{tabular}{|l|c|c|c|c|c|}
\hline Fatty acid & Stearic & Oleic & Linoleic & Linolenic & Ricinoleic \\
\hline Palmitic & $0.702^{* *}$ & $0.786^{* *}$ & $0.865^{* * *}$ & 0.384 & $-0.869^{* *}$ \\
\hline Stearic & & $0.832^{* *}$ & $0.793^{* * *}$ & $0.570^{* *}$ & $-0.877^{* *}$ \\
\hline Oleic & & & $0.918^{* *}$ & $0.647^{* *}$ & $-0.967^{* *}$ \\
\hline Linoleic & & & & $0.664^{* *}$ & $-0.978^{* *}$ \\
\hline Linolenic & & & & & $-0.676^{* *}$ \\
\hline
\end{tabular}

The presence of the hydroxyl group in ricinoleic acid and ricinoleic acid derivatives provides a functional group location for performing a variety of chemical reactions including halogenations, dehydration, alkoxylation, esterification, and sulfation.

This functionality allows the castor oil to be used in industrial applications such as paints, coatings, inks, and lubricants (Dunford, 2012).

The of GC-FID revealed that the unsaturated fatty acids (UFA) composition was between $96.5 \%$ and $99.77 \%$ and saturated fatty acid (SFA) ranged between $2.23 \%$ and $3.49 \%$ (Table 5).
Oleic (MUFA) / Ricinoleic acid (O/R) ratio

The Oleic (MUFA) / Ricinoleic acid ratio among the all 14 genotypes varied from 0.037 (RG 357) to 0.057 (RG 311) (Table 6). High oleic and low ricinoleic acid content in castor oil could have industrial uses requiring high oxidative stability such as bio fuel applications requiring lower ricinoleic acid percentages than the standard castor oil (Rajos et al., 2004).

\section{Oil stability index}

In the present study all the genotypes studied have Oleic/Linoleic ratio in range of $0.78 \%$ 
(RG 3445) to $0.91 \%$ (RG 3467). High O/L ratio indicated higher oil stability of genotype (Shah et al., 2014). The presence of antioxidants is higher in cold extracted oils than solvent extracted or pure methyl esters.

In conclusion, on the basis of present study it can be concluded that among the inbreds studied, the maximum weight of 100 seed was $39 \mathrm{~g}$ in RG 380, while maximum oil content was 50.7 and 50.6 in RG 311 and RG 330 respectively. The highest seed yield was 4987 $\mathrm{kg} / \mathrm{ha}$ in RG 63, $4408 \mathrm{~kg} / \mathrm{ha}$ in RG 311 and $4373 \mathrm{~kg} / \mathrm{ha}$ in RG 358. The maximum value of ricinoleic acid was $89.83 \%$ recorded in $\mathrm{RG}$ 357 inbred. The present study is of vital importance for the selection of male parents for high ricinoleic acid castor hybrid.

\section{References}

Abitogun, A., Alademeyin, O. and Oloye, D. 2009. Extraction and Characterization of Castor Seed Oil. The Internet J. Nutri. Wellness, 8(2).

Chapman, H.D., and Pratt, P.F.1961. Methods of Analysis for soils, plants and water. Univ. California, Berkeley, CA, USA. p 309.

Chesnin, L. and Yien, C.H. 1950. Turbidimetric determination of available sulphates. Soil Sci. Society of America J., 15: 149-151.

Dunford, N.T. 2012. Food and Industrial Bioproducts and Bioprocessing. John Wiley and Sons. 392p.

Isah, A.G. 2006. Production of detergent from castor oil. Leonardo Electronic J. Practices and Technologies, 9: 153-160.

Jackson, M.L. 1967. Soil Chemical Analysis Prentice Hall of India Pvt. Ltd., New Delhi; p. 205.
Lakshminarayana, G., Paulose, M.N. and Neeta Kumari, B. 1984. Characteristics and composition of newer varieties of Indian Castor seed and oil. The J. American Oil Chemists' Society (JAOCS), 61:1871-2.

Mutlu, H. and Meier, M.A.R. 2010. Castor Oil as a Renewable Resource for the Chemical Industry. European J. Lipid Sci. Technol., 112: 10-30.

Olsen, S.R., Cole, C.V., Watambe F.S. and Dean, L.A. 1954. Estimation of available phosphorus in soil by extraction with $\mathrm{NaHCO}_{3}$, U.S.D.A. Ciraza (Quoted from, Method of soil Analysis, C.A. Black 2nd ed.) 1165 Am. Soc. Agron., Inc. Medision Wisconsin, USA.

Piper, C.S. 1950. Soil and Plant Analysis. The University of Adelaide Press, Adelaide, Australia, $368 \mathrm{p}$.

Rojas, B.P., Haro, A.D., Munoz, J. and Martinez, J.M.F. 2004. Isolation of a natural mutant in castor with high oleic/low ricinoleic acid content in the oil. Crop Sci., 44:76-80.

Shah, S.K., Patel, M.K., and Patel, P.S. 2014. Prospects of castor (Ricinus Communis L.) genotypes for biodiesel production. GAU Res. J., 39(1): 28-34.

Subbiah, B.V. and Asija, G.L. 1956. A rapid procedure for the determination of available nitrogen in soil. Curr. Sci., 25: 259-260.

Walkley, A. and Black. 1947. A critical examination of a rapid method for determining organic carbon in soils: Effect of variations in digestion conditions and of organic soil constituents. Soil Sci., 63: 251263.

Yadav, Praduman and Murthy, I.Y.L.N. 2016. Calibration of NMR Spectroscopy for Accurate Estimation of Oil Content in Sunflower, Safflower and Castor Seeds. Curr. Sci., 110(1): 73-76.

\section{How to cite this article:}

Shah, S.K., A.V. Joshi, A.M. Patel and Patel, D.K. 2017. Screening of Castor Genotypes for Ricinoleic Acid Content. Int.J.Curr.Microbiol.App.Sci. 6(8): 1318-1324.

doi: https://doi.org/10.20546/ijcmas.2017.608.160 